\title{
Perinatal and Wharton's Jelly-Derived Mesenchymal Stem Cells in Cartilage Regenerative Medicine and Tissue Engineering Strategies
}

\author{
Melania Lo Iacono ${ }^{1, \S}$, Rita Anzalone ${ }^{*}, 1$, , Simona Corrao ${ }^{1}$, Mario Giuffrè ${ }^{2}$, Antonino Di Stefano ${ }^{3}$, \\ Pantaleo Giannuzzi ${ }^{4}$, Francesco Cappello ${ }^{1}$, Felicia Farina ${ }^{1}$ and Giampiero La Rocca ${ }^{1}$

\begin{abstract}
${ }^{I}$ Sezione di Anatomia Umana, Dipartimento di Biomedicina Sperimentale e Neuroscienze Cliniche, Università degli Studi di Palermo, Palermo, Italy

${ }^{2}$ Unità Complessa di Pediatria e Terapia Intensiva Neonatale, Dipartimento Universitario Materno Infantile, Università degli Studi di Palermo, Palermo, Italy
\end{abstract}

${ }^{3}$ Laboratorio di Citoimmunopatologia Apparato Cardio Respiratorio, Fondazione S. Maugeri, IRCCS, Istituto Scientifico di Veruno (NO), Italy

${ }^{4}$ Divisione di Cardiologia, Fondazione S. Maugeri, IRCCS, Istituto Scientifico di Veruno (NO), Italy

\begin{abstract}
Stem cells can be found in embryonic and extraembryonic tissues as well as in adult organs. In particular, research in the last few years has delineated the key features of perinatal stem cells derived from fetus-associated tissues. These cells show multiple differentiation potential, can be easily expanded ex vivo, and raise no ethical concerns as regards their use. Several reports indicate that cells isolated from Wharton's jelly (WJ), the main component of umbilical cord extracellular matrix, are multipotent stem cells that express markers shared by other mesenchymal stem cells (MSC) and give rise to different mature cell types belonging to all three germ layers. Moreover, WJ-MSC display promising hypoimmunogenic and immunomodulatory properties, since they express molecules able to modulate NK cells and expand regulatory $\mathrm{T}$-cell populations.

In this review, we focus on the use of perinatal stem cells for regenerative medicine aimed at cartilage repair and regeneration. Cartilage is a specialized connective tissue which has poor regeneration and self-repair capacity in vivo. Traumatic injury or autoimmune processes are among the main causes of cartilage damage and degeneration, for which new hope comes from tissue engineering using stem cells which have undergone chondrocyte-like differentiation. We analyze the in vitro and in vivo data on the use of perinatal stem cells, in particular WJ-MSC, for cartilage regenerative medicine. The high variability of cell sources, the use of different types of scaffolds and matrixes, and the administration of several combinations of growth factors clearly point out the need for further research to optimize this cellular therapy approach and translate the results obtained from bench to clinic.
\end{abstract}

Keywords: Articular cartilage, Chondrocytes, Differentiation markers, Extracellular matrix, Mesenchymal stem cells, scaffolds, Tissue engineering, Umbilical cord, Wharton's jelly.

\section{INTRODUCTION}

The umbilical cord (UC) is an extraembryonic formation that constitutes the essential link between placenta and fetus during pregnancy. It is covered by the umbilical epithelium, called also amniotic epithelium, layered with cubic epithelial cells [1]. The inner structure of the umbilical cord is composed of umbilical vessels, two arteries and one vein, embedded in mucous connective tissue known as Wharton's jelly (WJ). It contains an abundant extracellular matrix composed of sparse collagen fibers and an amorphous substance. The main role of Wharton's jelly is to prevent torsion, compression and bending of the vessels, maintaining the two-way flow of blood between maternal and fetal circulations. WJ is rich in proteoglycans such as hyaluronic

*Address correspondence to this author at the Sezione di Anatomia Umana, Dipartimento di Biomedicina Sperimentale e Neuroscienze Cliniche, Università degli Studi di Palermo, Via del Vespro 129, 90127 Palermo, Italy; Tel: 0039-091-6553506; Fax: 0039-091-6553580;
E-mails: ranzalone@hotmail.com, rita.anazalone@unipa.it

${ }^{\S}$ The two authors contributed equally to this paper acid and two cell types: myofibroblasts and fibroblast-like cells [2]. Weiss and co-workers have shown that Wharton's jelly cells (WJC) express osteopontin gene [3], a major component of the hematopoietic stem cell niche and a regulator of hematopoietic progenitor cells [4]. Hyaluronic acid is another main component of the hematopoietic stem cell niche and WJC are a likely source of hyaluronic acid [5]. The expression of such molecules may in part explain the ex vivo hematopoietic expansion features of WJC [6]. Furthermore, WJC favor the in vivo engraftment of hematopoietic stem cells [7, 8]. In addition, WJC also promote growth of embryonic stem cells and embryonic-like stem cells [9].

\section{MAIN FEATURES OF WHARTON' S JELLY MESENCHYMAL STEM CELLS}

Of the two cell types described in Wharton's jelly [2], myofibroblasts have ultrastructural characteristics of both 
fibroblasts and smooth muscle cells. They could play a role in fibrogenesis and contraction. [10]. Fibroblast-like cells, which constitute the mesenchymal stem cells (MSC) population, are multipotent stem cells, grow robustly in vitro, can be deep-frozen for long-term storage, and maintain a morphology similar to fibroblasts during their culture.

WJ-MSC show a phenotype closely resembling that of bone marrow mesenchymal stem cells (BM-MSC): in fact they express CD10, CD13, CD29, CD44, CD49e, CD73, CD90, CD105, CD166 and HLA class I. Like BM-MSC, they lack expression of hematopoietic markers such as CD34 and CD45, endothelial markers (CD31, vWF) and HLA-DR $[3,6,11]$. Moreover, and in contrast to BM-MSC, some preparations of WJ-MSC express CD117 [12], CD68 [13], and CD14 [14]. More recently, transcriptomic analyses allowed to deep-define the breadth of differences between WJ-MSC and other MSC populations [15].

Recent research by our group and others has demonstrated that WJ-MSC express mesodermal markers such as vimentin and $\alpha$-smooth muscle actin; endodermal markers like Gata-4, Gata-5, Gata-6, HNF4- $\alpha$; and neuro-ectodermal markers like nestin, neuron specific enolase (NSE) and glial fibrillary acid protein (GFAP). These data support the notion that these cells can differentiate towards different mature cell types derived from all three germ layers [12]. As for other MSC populations, according to the Position Statement of the International Society for Cellular Therapy, WJ-MSC are defined as multipotent stem cells since they can differentiate into at least three different cellular lineages: osteoblasts, adipocytes and chondrocytes [16].

WJ-MSC cultured in a medium opportunely supplemented with factors inducing osteogenic differentiation can express osteonectin, osteopontin, periostin and runx2 genes and proteins. Moreover, the acquisition of an osteoblast-like phenotype can be demonstrated by histological stains such as Alizarin Red and Von Kossa, used to visualize calcium deposits in the extracellular matrix $[12,17]$.

After culture with adipogenic induction medium, WJMSC develop lipid vacuoles (which can be demonstrated by Oil Red O staining) and express proteins such as adiponectin, leptin and PPAR $^{-}$, confirming the acquisition of a differentiated phenotype $[12,18]$.

WJ-MSC can also differentiate into chondrocyte-like cells, which express specific proteins such as collagen type II, cartilage oligomeric matrix protein (COMP), and aggrecan [19]. Specific histological staining such as Alcian blue or Safranin O-Fast Green highlight the deposition of mucopolysaccharides and proteoglycans by differentiated cells [20].

Indeed, recent data have shown that the differentiative ability of WJ-MSC goes far beyond the classic connective tissue cell types [21]. Alaminos et al., demonstrated endothelial differentiation of WJ-MSC which expressed typical markers of the endothelial lineage [22-24]. Mitchell et al., highlighted WJ-MSC capacity to differentiate towards glial cells and neurons: induced cells expressed higher levels of neuronal markers such as NSE and GFAP than did undifferentiated cells [25]. Conconi and colleagues showed the myogenic differentiative potential of WJ-MSC cultured in a myogenic medium [26]. Wu et al., showed WJ-MSC to have myocardiocyte differentiation ability: induced cells expressed cardiac myosin and cardiac troponin T (cTnT) [27]. These same researchers showed that stem cells injected into the viable myocardium bordering an experimental infarcted area were incorporated into the vasculature and occasionally were positive for $\mathrm{cTnT}$ [27].

Apart from differentiation, another key property of MSC is the ability to reduce allogeneic lymphocyte proliferation in vitro and in vivo, with important consequences for the management of acute rejection of infused cells. Recently, several studies have shown that MSC express different molecules involved in the inhibition of T-cell proliferation and dendritic cell differentiation, and other molecules responsible for the induction of T-cell anergy and regulatory T-cell expansion. Thus it has been hypothesized that MSC may have a role in inducing tolerance in the host immune system.

In particular, we and others highlighted the expression of immunomodulatory molecules such as HLA-G, HLA-E, PGE2 and HGF in WJ-MSC [12, 28, 29]. The non-classical type I HLA molecules are involved in the induction of tolerance of NK-cells towards self cells. [30]. It has been reported that HLA-G expands CD4+CD25+ FOXP3+ regulatory $\mathrm{T}$ cells [31]. Moreover, contrary to human BM-MSC, WJ-MSC may show a different combination of expression of B7-costimulatory factors $\left(\mathrm{CD} 80^{+}, \mathrm{CD} 86^{-}\right)$. Numerous reports suggest that the expression of CD80 in the absence of CD86 could play a role in the induction of peripheral tolerance, perhaps synergistically with HLA-G $[32,33]$.

Such properties of WJ-MSC could further contribute to their therapeutic effect in autoimmune rheumatic diseases [34].

\section{FEATURES AND FUNCTIONS OF CARTILAGE}

Cartilage is an avascular tissue which is found in different parts of the body: on articular surfaces, and in the tracheobronchial tree, larynx, ribs, eyelids, ear and nasal skeleton [35].

In the fetus, most of the skeleton is composed of temporary cartilage that will eventually be replaced by bone. Permanent cartilage remains unossified during adult life. Cartilage is a semi-transparent, elastic but tough connective tissue composed of cells called chondro-cytes surrounded by a matrix consisting of glycoproteins known as chondroitin. According to the extracellular matrix features, cartilage can be classified into three different types: hyaline cartilage, white fibrocartilage, and yellow or elastic fibrocartilage.

Hyaline cartilage is semi-transparent and has a tough but elastic texture. The inner architecture is very simple; it is composed of chondrocytes arranged in groups of two or more, of rounded or bluntly angular form. A granular matrix is organized in concentric lines around cartilage lacunae, cavities occupied by a single chondrocyte which following the cellular divisions may generate an isogenic series of two, four, or eight cells. Hyaline cartilage is typically found in the trachea, larynx, and also at the ends of bones where joints are formed.

White fibrocartilage is a tougher tissue with a higher content of anelastic fibrillar collagen fibers. It is found in the 
intervertebral disks, articular disks and meniscus [36]. Fibrocartilage acts as a shock absorber, providing sturdiness without impeding movement.

Elastic fibrocartilage is a more elastic cartilage of the hyaline type; its matrix, in fact contains abundant elastic fibers. This type of cartilage is present in the external ear, epiglottis and in parts of the larynx. Elastic cartilage supports and maintains the shape of the structure in which it is found [36].

\subsection{Main Features of Articular Cartilage}

Articular cartilage is a type of hyaline cartilage with a granular matrix, and small chondrocytes and nuclei arranged in horizontal rows in the uppermost layer close to the surface, while nearer to the bone they are arranged in vertical rows. Articular cartilages have a tendency to split in a vertical direction; in disease this tendency becomes clearly manifest [36].

Articular cartilage load-bearing function results from the interaction between chondrocytes and extracellular matrix (ECM) [37]. Chondrocytes live with a low contribution of oxygen and glucose throughout life, in fact they are glycolytic cells [38]. Studies show that mesenchymal stem cells may differentiate towards chondrocyte-like cells in conditions of hypoxia [39].

The extracellular matrix is composed of three different groups of macromolecules: fibrillar and non-fibrillar collagens, proteoglicans and collagenous proteins. type II and XI give cartilage strength and ensure most of its mechanical properties [40-42]. Collagen type VI is typically localized around the chondrocytes, allowing their attachment to the extracellular matrix as well as being involved in transduction of diverse signals to cells. [37, 43-45]. Collagen type IX function is not clear, but it seems that, like collagen type II, it maintains the integrity of the extracellular matrix. Aggrecan (aggregating proteoglycans) embedded in the collagen mesh give to cartilage its stiffness to compression, resilience and long-term durability [37, 44, 46]. The extracellular matrix contains also small proteoglycans such as decorin, fibromodulin, and biglycan. Tenascin and fibronectin are further molecules which modulate the interactions between chondrocytes and the surrounding microenvironment [47]. Cartilage oligomeric matrix protein (COMP) and other non collagenous proteins are markers of cartilage turnover and degeneration and are upregulated following proinflammatory stimuli [48-50].

\subsection{Injury to Articular Cartilage}

High-impact long-term physical exercise, with intensive and repetitive physical stress, may induce alterations in cartilage ECM and therefore in chondrocyte functions, causing cartilage degeneration [51-53].

According to the World Health Organization (WHO), orthopaedic, rheumatic and musculoskeletal diseases are the main causes of disability today in the world. Osteoarthritis (OA) and rheumatoid arthritis (RA) are the principal diseases of the joints. The term "arthritis" literally means inflammation of the joint but, whereas in osteoarthritis inflammation is primarily the result of the pathogenetic process, in rheumatoid arthritis it is the main cause [37]. RA is an autoimmune disease in which the immune system attacks synovial joints and cartilage. At present the causes of this inflammatory disorder are unknown.

OA, also known as osteoarthrosis or degenerative joint disease, is one of the principal disorders in western countries which lead to lifetime disability. It can occur as a result of advancing age, obesity, trauma or infection of the joint. Osteoarthritis is defined as a disease of the elderly, but in recent years it has become widespread among younger people due to juvenile obesity. Pain, heat, swelling, stiffness and limited mobility are the main signs and symptoms of OA [38]. This disease involves articular cartilage, synovial membrane, subchondral bone and periarticular soft tissue [54]. Drugs used for osteoarthritis treatment reduce only pain and inflammation but fail to repair the articular cartilage.

Isolated chondral and osteochondral defects are other disorders which involve damage of the cartilage. They usually occur in adolescent or younger people without causing evident symptoms or joint degeneration $[55,56]$.

\section{REPAIR OF CARTILAGE}

Cartilage injury results from an imbalance between anabolic and catabolic functions of the chondrocytes. Furthermore, chondrocytes, the only cell type present in cartilage, are fed by diffusion via the synovial fluid thanks to the pumping action generated by compression of the articular cartilage. For these reasons, the growth and repair of cartilage is slow [35]. Two main procedures exist for replacing damaged articular cartilage: stimulation of articular cartilage repair and transplantation of connective tissue.

The penetration of subchondral bone, osteotomy, joint distraction, periosteum or perichondrium grafts, application or implant of growth factors or artificial matrices which promote cartilage formation and cell transplantation of chondrocytes and mesenchymal stem cells are some of the methods used to repair cartilage $[57,58]$.

Growth factors such as transforming growth factor- $\beta$ (TGF- $\beta$ ), bone morphogenetic proteins (BMP), insulin like growth factor (IGF) and hepatocyte growth factor (HGF) affect chondrocyte metabolism and chondrogenesis [59]. In particular, BMPs are secreted growth factors of the TGF- $\beta$ superfamily that promote ectopic cartilage and bone formation and regulate directly the expression of chondrocyte genes [60]. Normally bone matrix contains growth factors; in fact, in ostechondral injures and joint degeneration these molecules are released to repair damaged articular cartilage. These factors appear to have greater effects in the treatment of isolated chondral and osteochondral defects and mild degeneration of cartilage in younger people.

Regeneration or repair of cartilage using stem cells can involve use of synthetic or natural polymer scaffolds. Fibrin promotes the formation of cartilage tissue and the attachment of a construct to the recipient site [61]. Collagen is another element used for scaffolds, in that it is normally the main protein of the extracellular matrix of cartilage [62]. Porous polylactic acid, polytetrafluoroethylene, polyester are synthetic polymers applied to restore an articular surface. 


\section{THE USE OF PERINATAL STEM CELL TRANS- PLANTATION FOR CARTILAGE REPAIR}

Embryonic stem cells (ESC) are totipotent cells since they can generate all cellular types. They derive from embryo at the blastula stage. Their use involves embryo sacrifice within 14 days following fertilization, therefore generating ethical issues. ESC can be indefinitely propagated but their graft can cause teratoma formation. For these reasons, many researchers used adult stem cells.

Adult stem cells maintain normal turnover of organs, can differentiate into different cellular types, and can be isolated from adults or children without ethical issues.

Adult bone marrow mesenchymal stem cells (BM-MSC) have been amply investigated for regenerative medicine applications. They have fibroblast-like morphology, grow on plastic, differentiate into connective cellular types such as chondrocytes, osteoblasts and adipocytes, and exhibit immunosuppressive ability. While bone marrow represents the main source of mesenchymal cells used in clinical settings, the number of cells obtained is low [63] and decreases with donor age [64]. Therefore, different research groups have investigated perinatal stem cells, extracted from alternative sources such as human and animal extraembryonic tissues: placenta, amniotic membrane, umbilical cord blood, Wharton's jelly or umbilical cord stroma $[65,66]$. The results of chrondrogenic differentiation experiments with these stem cells types are discussed in the following sections of the manuscript and schematized in Table $\mathbf{1}$.

\subsection{Umbilical Cord Blood Mesenchymal Stem Cells}

Human umbilical cord blood (UCB) has emerged as a promising source of mesenchymal stem cells. UCB-MSC can readily differentiate into chondrocytes when cultured in a chondrogenic medium. Rebelatto and co-workers, in a comparative study designed to evaluate the chondrogenic differentiative potential of BM-MSC, UCB-MSC and adipose tissue mesenchymal stem cells (ADSC), demonstrated that UCB-MSC cultured for 21 days in three different chondrogenic media showed a morphology similar to chondrocytes, produced mucopolysaccharide, an indicator of chondrocyte differentiation, and expressed higher levels of type II collagen mRNA than non-induced MSC [67].

Subsequent studies investigated the chondrogenic potential of human UCB-MSC seeded in scaffolds composed of thermoreversible gelation polymer (TGP). UCB-MSC were embedded in the TGP in a chondrogenic differentiation medium supplemented with TGF- $\beta 3$ and ascorbic acid. After 1 week of induction, the UCB-MSC changed their fibroblastlike morphology to that of a spheroidal one and the size of the spheroid increased probably due to the abundant GAG accumulation in the extracellular matrix. Moreover, gene expression of type II collagen and aggrecan was more evident at week 3 and week 2 of induction, respectively, whereas SOX 9 gene was expressed stably during the entire 4 weeks of the induction phase. This study demonstrated that chemically synthesized TGP is a suitable three-dimensional system for differentiating UBC-MSC towards chondrocytes according to their characteristic morphology, GAG accumulation and gene expression [68].
Collagen is certainly the main component of the ECM. For this reason different researchers have used it as a carrier of MSC in three-dimensional systems. The terminal 10-20 amino acid residues of collagen do not participate in the helical structure formation, and the telopeptide regions are the primary cause of immunogenicity [69,70]. Atelocollagen lacks in these regions and therefore is considered a better carrier for chondrogenic culture systems. Choi and coworkers demonstrated a chondrogenic potential of human umbilical cord blood-derived multilineage progenitor cells (UCB-MLPC) in atelocollagen. The cells were embedded in an atelocollagen gel and cultured in chondrogenic induction medium, supplemented with TGF- $\beta 3$, for 3 weeks. The presence of type II collagen, assessed by immunofluorescence, and the expression of aggrecan, Sox-9, TGF- $\beta$ RI and type II collagen mRNA verified by RT-PCR confirmed the chondrogenic potential. Thanks to the atelocollagen gel culture system, the induced cells maintained a round morphology and expressed cartilage specific molecule such as type II collagen and GAG. Moreover, the stiffness of post-cultured atelo-collagen gel was higher than that of pre-cultured atelocollagen gel [71].

In recent years, animal models of chondrogenic differenttiation of UCB-MSC have also been explored. Preliminary studies carried out by Seo and colleagues highlighted the chondrogenic potential of canine UCB-MSC. The pellet obtained after 2-3 weeks of culture with a chondrogenic medium supplemented with BMP-2, appeared white in colour and formed aggregates in the bottom of the tube. Moreover, canine UCB-MSC showed positivity for Toluidine blue, a specific dye for the highly sulphated proteoglycans of cartilage matrices [72].

Reed et al., demonstrated the ability of horse UCB-MSC to differentiate into mesodermal cellular lineages. In particular, foal UCB-MSC were cultured in a chondrogenic medium supplemented with ascorbic acid, dexamethasone and TGF- $\beta 1$. Alcian blue and Safranin staining revealed the presence of mucopolysaccharides and glycosaminoglycans respectively, while molecular analysis highlighted expression of Sox 9 and COL2A1 mRNA. These data demonstrated that horse UBC-MSC can differentiate into chondrocyte-like cells and therefore could play a role in the treatment of horse cartilage diseases [73].

\subsection{Placenta-Derived Mesenchymal Stem Cells}

Although umbilical cord blood is a valid source of MSC, the frequency of these cells is low and the isolation method poses some problems. Therefore, studies have been carried out on MSC derived from placenta. Zhang and co-workers isolated mesenchymal cells from chorionic villi in the human placenta (hPDMSC) and evaluated their ability to differenttiate into chondrocyte-like cells both in vitro and in vivo. hPDMSC were cultured for 21 days in a chondrogenic medium consisting of dexametasone, BMP-2 and TGF- $\beta 3$. After a 3-week induction phase, the cellular pellet obtained was white and opaque, and after 1 week the cells had already changed their morphology. Toluidine blue staining revealed a metachromatic matrix, immunohistochemistry showed presence of type II collagen and RT-PCR highlighted the expression of COL2A1, COL10A1, BMP-2, BMP-2R and aggrecan [74]. In the presence of a three-dimensional 
scaffold composed of atelocollagen, hPDMSC differentiated towards chondrocytes, and toluidine blue staining and RTPCR confirmed the results of the pellet culture. After transplantation of the pre-induction hPDMSC-loaded collagen sponge into nude mice-generated cartilage or transplantation of hPDMSC in collagen sponge into articular osteochondral defects in nude rats, hypertrophic repair cartilage was formed. Toluidine blue staining was performed in both in vivo experiments [74].

Amniotic membrane is composed of two cellular types: human amniotic epithelial cells (hAEC) derived from embryonic ectoderm and human amniotic mesenchymal stromal cells derived from embryonic mesoderm (hAMSC). hAMSC are similar to BM-MSC: they show a fibroblasticlike morphology and can differentiate towards different mesodermal cellular lineages. Prado and colleagues, in a comparative study on the multilineage differentiation potential of both human amniotic cells, observed that hAMSC cultured in a medium supplemented with chondrogenic factors differentiated towards chondrocyte-like cells. The acquisition of chondrocyte phenotype was confirmed by toluidine blue staining and expression of Col II, aggrecan and Sox 9 by qRT-PCR and immunohystochemical analyses. In summary, this study showed hAMSC to have a better chondrogenic differentiation potential than hAEC [75].

\subsection{Mesenchymal Stem Cells Derived from Amniotic Fluid}

Recently multipotent stem cells have also been isolated from animal and human amniotic fluid (AF). AF-derived mesenchymal stem cells (AF-MSC) have a higher proliferative capacity, maintain their pluripotency for longer and differentiate towards several mesodermal cellular types. It has been hypothesized that these cells are in an intermediate developmental stage between embryonic stem cells and lineage-restricted adult stem cells [76].

Kolambkar and coworkers investigated the chondrogenic potential of AF-MSC in pellet and alginate hydrogel culture. After 3 weeks in pellet culture, the amount of GAG was higher if these cells were cultured in a medium supplemented with TGF- $\beta 1$ compared to with TGF- $\beta 3$ or TGF- $\beta 3+$ BMP-2. Histological staining confirmed the presence of GAG indicating the formation of a cartilaginous matrix. The chondrogenic potential of AF-MSC was demonstrated also in alginate gels in the presence of TGF- $\beta 1$, after 3 weeks. The differentiated cells expressed type II collagen, the main molecule of the cartilage ECM [77].

Kunisaki and colleagues observed cartilage formation from mesenchymal stem cells derived from ovine amniotic fluid. These cells were cultured as micromass pellet in a chondrogenic medium containing IGF-1 and TGF- $\beta 2$ for $6-$ 12 weeks. Moreover, they were seeded into biodegradable polyglycolic acid scaffolds cultured in chondrogenic medium within a rotating bioreactor for 10-15 weeks. Both in the micromass pellets and $3 \mathrm{D}$ engineered constructs, AF-MSC were capable of chondrogenic differentiation and showed lower collagen type II levels and higher elastin levels than native fetal hyaline cartilage. In summary, ovine AF-MSC differentiated towards cells with a histological pattern similar to that of fetal hyaline cartilage. Therefore they could be used for hyaline-type grafts [78].

The same researchers performed a comparative analysis of three-dimensional cartilagineous constructs engineered from different ovine perinatal mesenchymal sources such as amniotic fluid, neonatal bone marrow and umbilical cord blood. In particular, these cells were seeded in synthetic polyglycolic acid scaffolds and maintained in chondrogenic medium supplemented with TGF- $\beta 2$. After 12-15 weeks all constructs were compared to hyaline and elastic cartilage by gross inspection, histological staining and quantitative extracellular matrix assays. Findings showed that mesenchymal cells had lower levels of GAGs than native hyaline cartilage, and in particular AF derived constructs showed higher elastin levels than the other two constructs, being thus perfectly comparable to native elastic cartilage [79].

\subsection{Mesenchymal Stem Cells Derived from Human Umbilical Cord Stroma and Wharton's Jelly}

Umbilical cord (UC) is a non-controversial and noninvasive source of mesenchymal stem cells. In recent years, also these cells have been investigated for their differentiation ability towards chondrocytes.

Arufe and coworkers demonstrated that UC-MSC are able to differentiate into chondrocyte-like cells if cultured in a medium supplemented with ascorbic acid, transferrin, dexamethasone, retinoic acid and TGF- $\beta 3$ for up to 46 days. The acquisition of a chondrocyte phenotype was evaluated by expression of COL1, COL2 and COL10 at different days of culture by qRT-PCR and immunohistochemistry analysis. Moreover, a secretome study evaluated the expression of proteins such as decorin, galectin-1 and chitinase, typical of native cartilage ECM. The results highlighted chondrogenic ability of UC stroma-derived MSC and therefore their possible use for cell therapy in articular diseases [80].

Wang and colleagues demonstrated that seeding density of cells derived from Wharton's jelly (WJ-MSC) in polyglycolic acid scaffolds (PGA), in the presence of chondrogenic medium, had important effects on their chondrogenic potential. WJ-MSC at different density $(5,25$, and 50 million cells $/ \mathrm{ml}$ ) were cultured in a chondrogenic medium within PGA scaffolds for 4 weeks. Biochemical and immunohistochemical analyses showed more GAGs and collagen type I and II contents in higher density groups (25 and 50 million cells $/ \mathrm{ml}$ ) than in a lower density group ( 5 million cells $/ \mathrm{ml}$ ). Mechanical integrity was also maintained more in the higher density than lower density group. In conclusion, this study underlined the potential for chondrogenic differentiation by WJ-MSC in a three-dimensional system and the importance of higher seeding density to promote biosynthesis and mechanical integrity for a possible application in fibrocartilage tissue engineering [81].

More recently a comparative study between human BMMSC and human WJ-MSC for cartilage tissue engineering was performed. Both cell types were seeded on PGA scaffolds at 25 million cells $/ \mathrm{ml}$ and cultured in chondrogenic differentiation medium for 6 weeks. WJ-MSC produced more GAGs than BM-MSC at both 3 and 6 weeks. Moreover, COL1 production was higher in WJ-MSC at 6 
Table 1. Summary of Literature Reports Indicating the Differentiative Ability of Perinatal MSC Populations Towards Chondrocyte-Like Cells

\begin{tabular}{|c|c|c|c|c|}
\hline MSC population & Chondrocyte differentiation protocol & $\begin{array}{l}\text { Analysis of marker } \\
\text { expression }\end{array}$ & $\begin{array}{l}\text { Functional features and } \\
\text { positivity to histological stains }\end{array}$ & Ref. \\
\hline $\begin{array}{l}\text { Human Bone marrow } \\
\text { mesenchymal stem cells } \\
\text { HumanAdipose tissue } \\
\text { derived mesenchymal stem } \\
\text { cells } \\
\text { Human Umbilical cord blood } \\
\text { derived mesenchymal stem } \\
\text { cells(UCB-MSC) }\end{array}$ & $\begin{array}{l}\text { Three steps, } 21 \text { days protocol: } \\
\text { I step: DMEM-HG with } 15 \% \text { FCS, } \\
\text { dexamethasone, ascorbic acid } 2 \text {-phosphate, } \\
\text { sodium pyruvate, TGF- } \beta 1 \text {, insulin-transferrin- } \\
\text { selenium-X(ITS-X) } \\
\text { II step: DMEM-HG with } 1 \% \text { FCS, TGF- } \beta 1 \text {, } \\
\text { insulin, AA } \\
\text { III step: differentiation Basal Medium } \\
\text { Chondrocyte with hMSC chondrogenic } \\
\text { SingleQuots }\end{array}$ & $\begin{array}{l}\text { I. type II collagen by RT- } \\
\text { PCR and q-PCR }\end{array}$ & $\begin{array}{l}\text { Paraffin sections stained with HE, } \\
\text { Mallory or Toluidine Blue }\end{array}$ & [67] \\
\hline $\begin{array}{l}\text { Human Umbilical cord blood } \\
\text { derived mesenchymal stem } \\
\text { cells (UCB-MSC) }\end{array}$ & $\begin{array}{l}\text { One step, three weeks protocol: } \\
\text { UCB-MSC in the TGP cultured in DMEM with } \\
\text { AA, TGF- } \beta 3 \text {, sodium pyruvate, ITS+ Premix }\end{array}$ & $\begin{array}{l}\text { I. type II collagen, } \\
\text { aggrecan and SOX9 by } \\
\text { RT-PCR }\end{array}$ & $\begin{array}{l}\text { I. GAG accumulation by ELISA } \\
\text { II. DNA assay by Hoechst } 33258 \\
\text { fluorimetric detection method }\end{array}$ & [68] \\
\hline $\begin{array}{l}\text { Human Umbilical cord blood } \\
\text { derived multilineage } \\
\text { progenitor cells (MLPC) }\end{array}$ & $\begin{array}{l}\text { One step, three weeks protocol: } \\
\text { MLPC in atelocollagen for } 3 \text { weeks } \\
\text { In hMSC Chondrogenic BulletKit with TGF- } \beta 3\end{array}$ & $\begin{array}{l}\text { I. type II collagen by IF } \\
\text { II. type II collagen, Sox } 9 \text {, } \\
\text { aggrecan and TGF- } \beta \text { R } 1 \text { by } \\
\text { RT-PCR }\end{array}$ & & [71] \\
\hline $\begin{array}{l}\text { Canine umbilical cord blood } \\
\text { derived mesenchymal stem } \\
\text { cells }\end{array}$ & $\begin{array}{l}\text { One step- } 3 \text { weeks protocol: } \\
\text { DMEM with } 10 \% \text { FCS with BMP-2 }\end{array}$ & None & Toluidine Blue staining for GAGs & [72] \\
\hline $\begin{array}{l}\text { Equine umbilical cord blood } \\
\text { mesenchymal stem cells }\end{array}$ & $\begin{array}{l}\text { One step, } 21 \text { daysprotocol: } \\
\text { DMEM with ITS-X; TGF- } \beta 1\end{array}$ & $\begin{array}{l}\text { Sox } 9 \text { and collagen } 2 \text { AI by } \\
\text { RT-PCR after } 7 \text { and } 21 \\
\text { days }\end{array}$ & $\begin{array}{l}\text { I. Alcian Blue stain for presence of } \\
\text { mucopolysaccharides } \\
\text { II. Safranin staining for GAGs }\end{array}$ & [73] \\
\hline $\begin{array}{l}\text { Human Mesenchymal } \\
\text { progenitor cells derived from } \\
\text { chorionic villi (hPDMC) }\end{array}$ & $\begin{array}{l}\text { Pellet culture: DMEM-HG with TGF- } \beta 3 \text {, dex, } \\
\text { BMP-2, ascorbate-2-phosphate,praline, pyruvate, } \\
\text { ITS+Premix for } 21 \text { days } \\
\text { Culture in atelocollagen gel: DMEM-HG with } \\
\text { TGF- } \beta 3 \text {, dexamethasone, BMP- } 2 \text {, ascorbate-2- } \\
\text { phosphate,praline pyruvate, ITS+Premix for } 3 \\
\text { weeks }\end{array}$ & $\begin{array}{l}\text { Pellet culture: } \\
\text { I type II collagen by IHC } \\
\text { II. Sox 9, COL2A1, } \\
\text { aggrecan, COL10A1, } \\
\text { BMP-2, BMP-6 by RT - } \\
\text { PCR } \\
\text { Culture in atelocollagen } \\
\text { gel: } \\
\text { Sox 9, COL2A1, } \\
\text { aggrecan, COL10A1, } \\
\text { BMP-2, BMP-6 by RT - } \\
\text { PCR }\end{array}$ & $\begin{array}{l}\text { In vitro: toluidine blue staining for } \\
\text { GAGs in pellet culture and culture } \\
\text { in atelocollagen } \\
\text { In vivo: subcutaneous } \\
\text { transplantation of hPDMC in } \\
\text { atelocollagen sponge into nude } \\
\text { mice. } \\
\text { Toluidine Blue for metachromic } \\
\text { matrix } \\
\text { In vivo: transplantation of hPDMC } \\
\text { in collagen sponge into articular } \\
\text { osteochondral defect in nude rats. } \\
\text { Toluidine blue staining } \\
\text { Expression of } \beta-2 \text { microglobulin } \\
\text { by FITC }\end{array}$ & [74] \\
\hline $\begin{array}{l}\text { Human amniotic epithelial } \\
\text { cells } \\
\text { Human amniotic membrane } \\
\text { derived mesenchymal stem } \\
\text { cells }\end{array}$ & $\begin{array}{l}\text { Two steps, } 23 \text { days protocol: } \\
\text { DMEM with } 15 \% \text { FBS, AA, MTG for } 2 \text { days. } \\
\text { DMEM with } 15 \% \text { knockout serum replacement, } \\
\text { AA, Dex, transferrin, RA and TGF- } \beta 3 \text { for } 21 \\
\text { days. }\end{array}$ & $\begin{array}{l}\text { I.Collagen I, collagen II, } \\
\text { aggrecan by IHC } \\
\text { II. Collagen II, Sox 9, } \\
\text { aggrecan by qRT-PCR }\end{array}$ & $\begin{array}{l}\text { Toluidine blue staining for } \\
\text { proteoglycans }\end{array}$ & [75] \\
\hline $\begin{array}{l}\text { Human Amniotic fluid } \\
\text { derived mesenchymal stem } \\
\text { cells }\end{array}$ & $\begin{array}{l}\text { Cell culture: one step protocol, for } 3 \text { weeks: } \\
\text { DMEM-HG with ITS+Premix, penicillin, } \\
\text { streptomycin, L-glutamine, dexamethasone, L- } \\
\text { proline, ascorbic-2-phosphate and TGF- } \beta 1 \text {, TGF- } \\
\beta 3 \text {, BMP-2, IGF-1 } \\
\text { Alginate gel: one step protocol for } 3 \text { weeks: } \\
\text { DMEM-HG with penicillin, streptomycin, L- } \\
\text { glutamine; after solidification in basal medium } \\
\text { with TGF- } \beta 1\end{array}$ & $\begin{array}{l}\text { Cell culture: } \\
\text { Type II collagen by IHC } \\
\text { Alginate gel: } \\
\text { Type II collagen by IF }\end{array}$ & $\begin{array}{l}\text { Cell culture } \\
\text { DNA assay by Hoescht } 33258 \text { dye } \\
\text { GAG assay by dimethyl-methylene } \\
\text { blue } \\
\text { Alginate gel: None }\end{array}$ & [77] \\
\hline $\begin{array}{l}\text { Ovine amniotic fluid derived } \\
\text { mesenchymal progenitor } \\
\text { cells }\end{array}$ & $\begin{array}{l}\text { Micromass pellet: one step protocol, 6-12 weeks } \\
\text { DMEM-HG with dexamethasone, ascorbic acid } \\
\text { 2-phosphate, penicillin G sodium, streptomycin } \\
\text { sulphate, sodium pyruvate, L-proline, TGF- } \beta 2 \text {, } \\
\text { IGF-1, ITS-plus }\end{array}$ & $\begin{array}{l}\text { Micromass pellet } \\
\text { I. Aggrecan by IHC }\end{array}$ & $\begin{array}{l}\text { Micromass pellet } \\
\text { I. toluidine blue staining for GAGs } \\
\text { II. H\&E staining }\end{array}$ & [78] \\
\hline
\end{tabular}


(Table 1) Contd....

\begin{tabular}{|c|c|c|c|c|}
\hline MSC population & Chondrocyte differentiation protocol & $\begin{array}{l}\text { Analysis of marker } \\
\text { expression }\end{array}$ & $\begin{array}{l}\text { Functional features and } \\
\text { positivity to histological stains }\end{array}$ & Ref. \\
\hline & $\begin{array}{l}3 \text { D engineered constructs: one step protocol, } 10 \text { - } \\
15 \text { weeks: } \\
\text { DMEM-HG with dexamethasone, ascorbic acid } \\
\text { 2-phosphate, penicillin G sodium, streptomycin } \\
\text { sulphate, sodium pyruvate, L-proline, TGF- } \beta 2 \text {, } \\
\text { IGF-1, ITS-plus }\end{array}$ & $\begin{array}{l}3 D \text { engineered constructs } \\
\text { I. proteoglycans and } \\
\text { aggrecan by IHC }\end{array}$ & $\begin{array}{l}3 D \text { engineered constructs } \\
\text { I. toluidine blue staining for GAGs } \\
\text { II. quantitative GAGs assay } \\
\text { III. quantitative DNA assay } \\
\text { IV. quantitative collagen type II } \\
\text { assay }\end{array}$ & \\
\hline $\begin{array}{l}\text { Ovine amionitic fluid } \\
\text { mesenchymal progenitor } \\
\text { cells (MPC) } \\
\text { Ovine neonatal bone } \\
\text { marrow MPC } \\
\text { Ovine umbilical cord blood } \\
\text { MPC }\end{array}$ & $\begin{array}{l}\text { One step, } 12 \text { weeks protocol: } \\
\text { Cells seeded in polyglycol acid in } \\
\text { DMEM with dexamethasone, ascorbic acid 2- } \\
\text { phosphate, penicillin G sodium, streptomycin } \\
\text { sulphate, sodium pyruvate, L-proline, TGF- } \beta 1 \text {, } \\
\text { IGF-1, ITS+ }\end{array}$ & $\begin{array}{l}\text { Aggrecan and cartilage } \\
\text { link protein by IHC }\end{array}$ & $\begin{array}{l}\text { Toluidine blue staining for GAG } \\
\text { Von Gieson staining for elastin } \\
\text { q-GAG assay } \\
\text { q-DNA assay } \\
\text { q- } \alpha \text {-elastin }\end{array}$ & [79] \\
\hline $\begin{array}{l}\text { Human umbilical cord } \\
\text { stroma derived mesenchymal } \\
\text { stem cells }\end{array}$ & $\begin{array}{l}\text { One step protocol, for 4-7-14-28-46 days: } \\
\text { DMEM with } 15 \% \text { knockout serum replacement, } \\
\text { AA, transferrin, dexamethasone, RA, TGF- } \beta 3\end{array}$ & $\begin{array}{l}\text { I. COL1, COL2, COL10 } \\
\text { by IHC } \\
\text { II. COL1, COL2, COL10 } \\
\text { by qRT-PCR }\end{array}$ & $\begin{array}{l}\text { I. H\&E to evaluate distribuition of } \\
\text { matrix } \\
\text { II. Safranin O staining for } \\
\text { proteoglycans } \\
\text { III. Alizarin blue staining for } \\
\text { polysaccharides } \\
\text { IV. densitometric analysis of } \\
\text { COL1, COL2, COL10 } \\
\text { V. secretome analysis during } \\
\text { chondrogenesis of } 342 \text { proteins }\end{array}$ & [80] \\
\hline $\begin{array}{l}\text { Wharton's Jelly derived } \\
\text { mesenchymal stem cells } \\
\text { (WJ-MSC) }\end{array}$ & $\begin{array}{l}\text { One step, } 4 \text { weeks protocol: } \\
\text { WJ-MSC seeded in PGA scaffolds } \\
\text { DMEM-HG with non essential amino acid, } \\
\text { ascorbic acid 2-phosphate, dexamethasone, } \\
\text { sodium pyruvate, L-proline, TGF- } \beta 1\end{array}$ & $\begin{array}{l}\text { COL1, COL2, aggrecan } \\
\text { by IHC }\end{array}$ & $\begin{array}{l}\text { I. GAGs assay } \\
\text { II. hydroxyproline assay } \\
\text { III. Mechanical tests }\end{array}$ & [81] \\
\hline $\begin{array}{l}\text { Bone marrow derived } \\
\text { mesenchymal stem cells } \\
\text { Wharton's Jelly derived } \\
\text { mesenchymal stem cells }\end{array}$ & $\begin{array}{l}\text { One step- WJ-MSC into PGA scaffodls for } 6 \\
\text { weeks } \\
\text { DMEM-HG with non essential amino acid, } \\
\text { ascorbic acid 2-phosphate, dexamethasone, } \\
\text { sodium pyruvate, L-proline, TGF- } \beta 1\end{array}$ & $\begin{array}{l}\text { I. COL1,COL2, aggrecan } \\
\text { by IHC } \\
\text { II. COL1,COL2, aggrecan } \\
\text { by RT-PCR }\end{array}$ & $\begin{array}{l}\text { I.Hematoxylin staining } \\
\text { II. DNA content assay } \\
\text { III. GAGs content assay } \\
\text { IV. hydroxyproline content assay }\end{array}$ & [82] \\
\hline $\begin{array}{l}\text { Wharton's Jelly derived } \\
\text { mesenchymal stem cells }\end{array}$ & $\begin{array}{l}\text { WJ-MSC into PLLA scaffold for } 3 \text { weeks } \\
\text { DMEM-HG with non essential amino acid, } \\
\text { ascorbic acid 2-phosphate, dexamethasone, } \\
\text { sodium pyruvate, L-proline, TGF- } \beta 1 \\
\text { Osteochondral composites:for } 3 \text { weeks } \\
\text { DMEM-LG with FBS, ascorbic acid 2-phosphate, } \\
\text { dexamethasone, L-proline, IGF-1 }\end{array}$ & $\begin{array}{l}\text { I. COL1, COL2, aggrecan } \\
\text { by IHC } \\
\text { II. COL1,COL2, aggrecan } \\
\text { by RT-PCR }\end{array}$ & $\begin{array}{l}\text { I. DNA content assay } \\
\text { II. GAGs content assay } \\
\text { III. hydroxyproline content assay } \\
\text { IV. calcium deposition assay } \\
\text { V. Safranin O staining }\end{array}$ & [84] \\
\hline $\begin{array}{l}\text { Equine umbilical cord matrix } \\
\text { cells }\end{array}$ & $\begin{array}{l}\text { One step, } 21 \text { days protocol: } \\
\text { Serum-free DMEM-LG with ITS + premix TGF- } \\
\beta 1\end{array}$ & None & I. toluidine blue staining & {$[85]$} \\
\hline
\end{tabular}

Abbreviations: DMEM: Dulbecco's Modified Eagle's Medium; HG: high glucose, LG: low glucose, FCS: fetal calf serum; FBS: fetal bovine serum, TGF- $\beta$ : transforming growth factor- $\beta$, AA: ascorbic acid; ITS: insulin-transferrin-selenite; HE: haematoxylin-eosin; GAGs: glycosaminoglycans; ITS+Premix: insulin, transferring, selenius acid, bovine serum albumin, linoleic acid; RA: retinoic acid; MTG: monothioglycerol; IGF: insulin growth factor; COLI: collagen I, COL II: collagen II, Col10: collagen 10, BMP-2: bone morphogenetic protein-2.

weeks. Based on the ECM-molecules expression profile of WJ-MSC, consisting of a large amount of type I collagen, lower content of type II collagen and moderate amounts of aggrecan, these cells could be considered candidates for fibrocartilage tissue engineering such as for the temporomandibular joint disc or the knee meniscus [82].

In a very recent report, Fong and co-workers showed that human WJ-MSC undergo enhanced chondrogenic differentiation when cultured on nanofibrous substrates with a sequential two cultures medium environment. The resear- chers highlighted that in particular WJ-MSC were able to upregulate the production of hyaluronic acid and GAGs, as well as the expression of key genes as SOX9, COMP, Collagen type II and FMOD [83].

Osteochondral tissue is composed of cartilage and bone: in osteochondral defects both tissues necessitate regeneration. WJ-MSC are considered excellent candidates for osteochondral tissue engineering. Wang and co-workers developed a supportive structure which mimics native osteochondral tissue. Two groups of WJ-MSC were seeded in different 
poly-L-lactic-acid (PLLA) scaffolds with chondrogenic and osteogenic medium respectively for 3 weeks. After this period of culture, chondrogenic and osteogenic constructs were sutured together surgically to create four different osteochondral assemblies: one with two chondrogenic constructs, one with two osteogenic constructs, one with a chondrogenic and an osteogenic construct and the last with a chondrogenic and an osteogenic construct with a layer of undifferentiated WJ-MSC. Histological staining and immunohistochemical analysis confirmed the presence of GAG, type I collagen and calcium at the interface between chondrogenic and osteogenic sections when a layer of undifferentiated cells was present with respect to the other three investigated composites [84].

Hoynowski and coworkers showed the chondrogenic differentiation potential of WJ-MSC derived from horse. These cells, cultured in a chondrogenic medium, changed their morphology from fibroblastoid to spheroid. Toluidine blue staining highlighted the presence of aggregates transformed into spherical masses after chondrogenic induction. This study demonstrated that equine WJ-MSC can proliferate extensively, differentiate into several cellular types and therefore could play a role in stem cell-based therapies in the horse [85].

\section{CONCLUSIONS AND FUTURE PERSPECTIVES}

Cartilage tissue engineering using multipotent stem cells is an evolving field in regenerative medicine. The low in vivo self-repair of cartilage and the occurrence of a number of dysfunctions in cartilagineous tissues, of both post-traumatic and autoimmune origin, render more compelling the need for successful cellular therapy approaches. In this perspective, perinatal stem cells, derived from fetusassociated structures at birth, share a number of positive features which enable their use for these tissue engineering applications. In particular, Wharton's jelly-derived cells are being viewed as a very promising cellular source due to both their differentiative and immunomodulatory properties. WJMSC have been demonstrated to successfully differentiate into cells resembling mature chondrocytes. Moreover, their peculiar features of low immunogenicity and their potential to induce immune tolerance in the host further justify the efforts for their use in osteoarthritis, rheumatoid arthritis and other disease settings. Further research is needed to standardize the differentiation protocols used as well as the scaffold composition. However, the in vitro and in vivo results obtained so far are encouraging and indicate that one of the foremost uses of WJ-MSC could be in tissue engineering of cartilagineous tissues.

\section{ACKNOWLEDGEMENTS}

We thank Rosemary Allpress for her revision of the English language.

\section{CONFLICT OF INTEREST}

Dr. La Rocca is member of the Scientific Board of Auxocell Laboratories, Inc. The funders had no role in article design, data collection, decision to publish, or preparation of the manuscript.

\section{REFERENCES}

[1] Mizoguchi M, Suga Y, Sanmano B, et al. Organotypic culture and surface plantation using umbilical cord epithelial cells: morphogenesis and expression of differentiation markers mimicking cutaneous epidermis. J Dermatol Sci 2004; 35: 199-206.

[2] Can A, Karahuseyinoglu S. Human umbilical cord stroma with regard to the Source of foetus-derived stem cells. Stem Cells 2007; 25: 2886-95.

[3] Weiss ML, Medicetty S, Bledsoe AR, et al. Human umbilical cord matrix stem cells: Preliminary characterization and effect of transplantation in a rodent model of Parkinson's disease. Stem Cells 2006; 24: 781-92.

[4] Nilsson SK, Johnston HM, Whitty GA, et al. Osteopontin, a key component of the hematopoietic stem cell niche and regulator of primitive hematopoietic progenitor cells. Blood 2005; 106: 123239.

[5] Raio L, Cromi A, Ghezzi F, et al. Hyaluronan content of wharton's jelly in healthy and Down syndrome foetuses. Matrix Biol 2005; 24: 166-74.

[6] Lu LL, Liu YJ, Yang SG. Isolation and characterization of human umbilical cord mesenchymal stem cells with hematopoietic supportive function and other potentials. Haematologica 2006; 91 : 1017-26.

[7] Friedman R, Betancur M, Boissel L, et al. Umbilical cord mesenchymal stem cells: adjuvants for human cell transplantation. Biol Blood Marrow Transplant 2007; 13: 1477-86.

[8] De Bruyn C, Najar M, Raicevic G, et al. A rapid, simple, and reproducible method for the isolation of mesenchymal stromal cells from Wharton's jelly without enzymatic treatment. Stem Cells Dev 2011; 20: 547-57.

[9] Saito S, Ugai H, Sawai K, et al. Isolation of embryonic stem-like cells from equine blastocysts and their differentiation in vitro. FEBS Lett 2002; 531: 389-96.

[10] Małkowski A, Sobolewski K, Jaworski S, Ban'kowski E. TGF- $\beta$ binding in human Wharton's jelly. Mol Cell Biochem 2008; 311: 137-43.

[11] Wang HS, Hung SC, Peng ST, et al. Mesenchymal stem cells in theWharton's jelly of the human umbilical cord. Stem Cells 2004; 22: 1330-37.

[12] La Rocca G, Anzalone R, Corrao S, et al. Isolation and characterization of Oct-4+/HLA-G+ mesenchymal stem cells from human umbilical cord matrix: differentiation potential and detection of new markers. Histochem Cell Biol 2009; 131: 267-82.

[13] La Rocca G, Anzalone R, Farina F. The expression of CD68 in human umbilical cord mesenchymal stem cells: New evidences of presence in non-myeloid cell types. Scand J Immunol 2009; 70: 161-2.

[14] Kita K, Gauglitz G, Phan CC, et al. Isolation and characterization of mesenchymal stem cells from the sub-amniotic human umbilical cord lining membrane. Stem Cells Dev 2010; 19: 491-502.

[15] Fong C-Y, Chak L-L, Biswas A, et al. Human Wharton's Jelly Stem cells have unique transcriptome profiles compared to human embryonic stem cells and other mesenchymal stem cells. Stem Cell Rev Rep 2011; 7: 1-16.

[16] Dominici M, Le Blanc K, Mueller I, et al. Minimal criteria for defining multipotent mesenchymal stromal cells. The international society for cellular therapy position statement. Cytotherapy 2006; 8: 315-17.

[17] Zuk PA, Zhu M, Ashjian P, et al. Human adipose tissue is a source of multipotent stem cells. Mol Biol Cell 2002; 13: 4279-92.

[18] Janderova L, McNeil N, Murrell N, et al. Human mesenchymal stem cells as an in vitro model for human adipogenesis. Obes Res 2003; 11: 65-73.

[19] Dvorakova J, Velebny V, Kubala L. Hyaluronan influence on the onset of chondrogenic differentiation of mesenchymal stem cells. Neuro Endocrinol Lett 2008; 29: 685-90.

[20] Steck E, Fischer J, Lorenz H, et al. Mesenchymal stem cell differentiation in an experimental cartilage defect: restriction of hypertrophy to bone-close neocartilage. Stem Cells Dev 2009; 18 : 969-78. 
[21] Anzalone R, Farina F, Zummo G, La Rocca G. Recent patents and advances on isolation and cellular therapy applications of mesenchymal stem cells from human umbilical cord Wharton's jelly. Recent Pat Regen Med 2011; 1: 216-27.

[22] Alaminos M, Pérez-Köhler B, Garzón I, et al. Transdifferentiation potentiality of human Wharton's jelly stem cells towards vascular endothelial cells. J Cell Physiol 2010; 223: 640-7.

[23] La Rocca G, Di Stefano A, Eleuteri E, et al. Oxidative stress induces myeloperoxidase expression in endocardial endothelial cells from patients with chronic heart failure. Basic Res Cardiol 2009; 104: 307-20.

[24] Anzalone R, La Rocca G, Di Stefano A, et al. Role of endothelial cell stress in the pathogenesis of chronic heart failure. Front Biosci 2009; 14: 2238-47.

[25] Mitchell KE, Weiss ML, Mitchell BM, et al. Matrix cells from Wharton's jelly form neurons and glia. Stem Cells 2003; 21: 50-60.

[26] Conconi MT, Burra P, Di Liddo R, et al. CD105(+) cells from Wharton's jelly show in vitro and in vivo myogenic differentiative potential. Int J Mol Med 2006; 18: 1089-96.

[27] Wu KH, Mo XM, Zhou B, et al. Cardiac potential of stem cells from whole human umbilical cord tissue. J Cell Biochem 2009; 107: 926-32.

[28] Najar M, Raicevic G, Boufker HI, et al. Mesenchymal stromal cells use PGE2 to modulate activation and proliferation of lymphocyte subsets: Combined comparison of adipose tissue, Wharton's Jelly and bone marrow sources. Cell Immunol 2010; 264: 171-9.

[29] Raicevic G, Najar M, Stamatopoulos B, et al. The source of human mesenchymal stromal cells influences their TLR profile as well as their functional properties. Cell Immunol 2011; doi: 10.1016/j.cellimm.2011.05.010

[30] Anzalone R, Lo Iacono M, Loria $\mathrm{T}$, et al. Wharton's jelly mesenchymal stem cells as candidates for beta cells regeneration: Extending the differentiative and immunomodulatory benefits of adult mesenchymal stem cells for the treatment of type 1 diabetes. Stem Cell Rev Rep 2011; 7: 342-63.

[31] Saas P, Tiberghien P, Rouas-Freiss N, et al. Human leukocyte antigen-G5 secretion by human mesenchymal stem cells is required to suppress T lymphocyte and natural killer function and to induce CD4+CD25highFOXP3+ regulatory T cells. Stem Cells 2008; 26: 212-22.

[32] Sansom DM, Manzotti CN, Zheng Y. What's the difference between CD80 and CD86? Trends Immunol 2003; 24: 313-8.

[33] Zhu XY, Zhou Y-H, Wang M-Y, et al. Blockade of CD86 signaling facilitates a Th2 bias at the maternal-fetal interface and expands peripheral $\mathrm{CD} 4+\mathrm{CD} 25+$ regulatory $\mathrm{T}$ cells to rescue abortion-prone fetuses. Biol Reprod 2005; 72: 338-45.

[34] MacDonald GIA, Augello A, De Bari C. Mesenchymal Stem Cells: Re-establishing Immunological tolerance in autoimmune rheumatic diseases. Arthritis Rheum 2011; doi: 10.1002/art.30474.

[35] Ogawa R. Recent patents on stem cell-mediated cartilage regeneration and repair. Recent Pat Regen Med 2011; 1: 118-22.

[36] Standring S, Ed. Gray's Anatomy. The anatomical basis of clinical practice. Elsevier: Amsterdam, 2008.

[37] Mobasheri A, Shakibaei M. Applications of mesenchymal stem cells in cartilage tissue engineering-part 1. Recent Pat Regen Med 2011; 1:30-41.

[38] Mobasheri A, Bondy CA, Moley K, et al. Facilitative glucose transporters in articular chondrocytes. Expression, distribution and functional regulation of GLUT isoforms by hypoxia, hypoxia mimetics, growth factors and pro-inflammatory cytokines. Adv Anat Embryol Cell Biol 2008; 200: 1-84.

[39] Murphy CL, Thoms BL, Vaghjiani RJ, Lafont JE. Hypoxia, HIF mediated articular chondrocyte function: Prospects for cartilage repair. Arthritis Res Ther 2009; 11:213.

[40] Buckwalter JA, Mankin HJ. Articular cartilage: Tissue design and chondrocyte-matrix interactions. Instr Course Lect 1998; 47: 47786.

[41] Eyre DR. Collagens and cartilage matrix homeostasis. Clin Orthop Relat Res 2004; (427 Suppl): S118-22.

[42] Kuettner KE, Aydelotte MB, Thonar EJ. Articular cartilage matrix and structure: A minireview. J Rheumatol Suppl 1991; 27: 46-8

[43] Guilak F, Alexopoulos LG, Upton ML, et al. The pericellular matrix as a transducer of biomechanical and biochemical signals in articular cartilage. Ann N Y Acad Sci 2006; 1068: 498-512.

[44] Roughley PJ, Lee ER. Cartilage proteoglycans: Structure and potential functions. Microsc Res Tech 1994; 28: 385-97.
[45] Zhang Z, Jin W, Beckett J, et al. A proteomic approach for the identification and localization of the pericellular components of chondrocytes. Histochem Cell Biol, 2011; DOI 10.1007/s00418011-0834-y.

[46] Luo W, Guo C, Zheng J, et al. Aggrecan from start to finish. J Bone Miner Metab 2000; 18: 51-6.

[47] Burton-Wurster N, Lust G, Macleod JN. Cartilage fibronectin isoforms: In search of functions for a special population of matrix glycoproteins. Matrix Biol 1997; 15: 441-54.

[48] Di Cesare PE, Carlson CS, Stolerman ES, et al. Increased degradation and altered tissue distribution of cartilage oligomeric matrix protein in human rheumatoid and osteoarthritic cartilage. J Orthop Res 1996; 14: 946-55.

[49] Zivanovic S, Rackov LP, Vojvodic D, Vucetic D. Human cartilage glycoprotein 39-biomarker of joint damage in knee osteoarthritis. Int Orthop 2009; 33: 1165-70.

[50] Zivanovic S, Rackov LP, Zivanovic A, et al. Cartilage oligomeric matrix protein - inflammation biomarker in knee osteoarthritis. Bosn J Basic Med Sci 2011; 11: 27-32.

[51] Buckwalter JA. Sports, joint injury, and posttraumatic osteoarthritis. J Orthop Sports Phys Ther 2003; 33: 578-88

[52] Sarzi-Puttini P, Cimmino MA, Scarpa R, et al. Osteoarthritis: An overview of the disease and its treatment strategies. Semin Arthritis Rheum 2005; 35(Suppl 1): 1-10

[53] Setton LA, Elliott DM, Mow VC. Altered mechanics of cartilage with osteoarthritis: Human osteoarthritis and an experimental model of joint degeneration. Osteoarthritis Cartilage 1999; 7: 2-14.

[54] Goldring MB, Goldring SR. Osteoarthritis. J Cell Physiol 2007; 213: 626-34

[55] Zarins B, Parsons C. Chondral injuries: Clinical overview. Operative Tech Orthop 1997; 7: 345-6.

[56] Messner K, Maletius W. The long-term prognosis for severe damage to weight-bearing cartilage in the knee. Acta Orthop Scand 1996; 67: 165-8.

[57] Buckwalter JA, Mankin HJ. Articular cartilage repair and transplantation. Arthritis Rheum 1998; 41: 1331-42.

[58] Kim AJ, Adkisson HD, Wendland M, et al. Juvenile chondrocytes may facilitate disc repair. Open Tissue Eng Regen Med J 2010; 3 28-35.

[59] Freyria AM, Mallein-Gerin F. Chondrocytes or adult stem cells for cartilage repair: The indisputable role of growth factors. Injury 2011; doi:10.1016/j.injury.2011.05.035

[60] Wozney JM. Bone morphogenetic proteins. Prog Growth Factor Res 1989; 1:267-80.

[61] Geistlich P, Spector M, Eckmayer Z. Resorbable extracellular matrix for reconstruction of cartilage tissue. WO9625961 (1996).

[62] Awad HA, Wickham MQ, Leddy HA, et al. Chondrogenic differentiation of adipose-derived adult stem cells in agarose, alginate, and gelatin scaffolds. Biomaterials 2004; 25: 3211-22.

[63] Fukuchi Y, Nakajima H, Sugiyama D, Hirose I, Kitamura T, Tsuji K. Human placenta derived cells have mesenchymal stem/ progenitor cell potential. Stem Cells 2004; 22(5): 649-58.

[64] Rao MS, Mattson MP. Stem cells and aging: Expanding the possibilities. Mech Aging Dev 2001; 122: 713-34.

[65] Romanov YA, Svintsitskaya VA, Smirnov VN. Searching for alternative sources of postnatal human mesenchymal stem cell: Candidate MSC-like from umbilical cord. Stem Cells 2003; 21: 105-10.

[66] Taghizadeh RR, Cetrulo KJ, Cetrulo CL. Wharton's jelly stem cells: Future clinical applications. Placenta 2011; doi: 10.1016/j.placenta.2011.06.010

[67] Rebelatto CK, Aguiar AM, Moretão MP, et al. Dissimilar differentiation of mesenchymal stem cells from bone marrow, umbilical cord blood, and adipose tissue. Exp Biol Med (Maywood) 2008; 233: 901-13.

[68] Kao I-T, Yao C-L, Chang Y-J, et al. Chondrogenic dfifferentiation of human mesenchymal stem cells from umbilical cord blood in thermoreversible Polymer. Chin J Physiol 2008; 51: 252-8.

[69] Lynn AK, Yannas IV, Bonfield W. Antigenicity and immunogenicity of collagen. J Biomed Mater Res B Appl Biomater 2004; $71: 343-54$

[70] Pontz B, Meigel W, Rauterberg J, et al. Localization of two species specific antigenic determinants on the peptide chains of calf skin collagen. Eur J Biochem 1970; 16: 50-4. 
[71] Choi YS, Im MW, Kim CS, et al. Chondrogenic differentiation of human umbilical cord blood-derived multilineage progenitor cells in atelocollagen. Cytotherapy 2008; 10: 165-73.

[72] Seo MS, Jeong YH, Park JR, et al. Isolation and characterization of canine umbilical cord blood-derived mesenchymal stem cells. J Vet Sci 2009; 10: 181-7.

[73] Reed SA, Johnson SE. Equine umbilical cord blood contains a population of stem cells that express Oct4 and differentiate into mesodermal and endodermal cell types. J Cell Physiol 2008; 215: 329-36.

[74] Zhang X, Mitsuru A, Igura K, et al. Mesenchymal progenitor cells derived from chorionic villi of human placenta for cartilage tissue engineering. Biochem Biophys Res Commun 2004; 340: 944-52.

[75] Díaz-Prado S, Muiños-López E, Hermida-Gómez $\mathrm{T}$, et al. Multilineage differentiation potential of cells isolated from the human amniotic membrane. J Cell Biochem 2010; 111: 846-57.

[76] De Coppi P, Bartsch G Jr, Siddiqui MM, et al. Isolation of amniotic stem cell lines with potential for therapy. Nat Biotechnol 2007; 25: 100-6.

[77] Kolambkar YM, Peister A, Soker S, et al. Chondrogenic differentiation of amniotic fluid-derived stem cells. J Mol Histol 2007; 38: 405-13.

[78] Kunisaki SM, Jennings RW, Fauza DO. Fetal cartilage engineering from amniotic mesenchymal progenitor cells. Stem Cells Dev 2006; 15: 245-53.

[79] Kunisaki SM, Fuchs JR, Steigman SA, Fauza DO. A comparative analysis of cartilage engineered from different perinatal mesenchymal progenitor cells. Tissue Eng 2007; 13: 2633-44.
[80] Arufe MC, De la Fuente A, Mateos J, et al. Analysis of the chondrogenic potential and secretome of mesenchymal stem Cells derived from human umbilical cord stroma. Stem Cells Dev 2011; 20: 1199-212.

[81] Wang L, Seshareddy K, Weiss ML, Detamore MS. Effect of initial seeding density on human umbilical cord mesenchymal stromal Cells for fibrocartilage tissue engineering. Tissue Eng Part A 2009; 15: 1009-17.

[82] Wang L, Tran I, Seshareddy K, Weiss ML, Detamore MS. A comparison of human bone marrow-derived mesenchymal stem cells and human umbilical cord-derived mesenchymal stromal cells for cartilage tissue engineering. Tissue Eng Part A 2009; 15: 225966.

[83] Fong C-Y, Subramanian A, Gauthaman K, et al. Human umbilical cord Wharton's jelly stem cells undergo enhanced chondrogenic differentiation when grown on nanofibrous scaffolds and in a sequential two-stage culture medium environment. Stem Cell Rev Rep 2011; DOI 10.1007/s12015-011-9289-8.

[84] Wang L, Zhao L, Detamore MS. Human umbilical cord mesenchymal stromal cells in a sandwich approach for osteochondral tissue engineering. J Tissue Eng Regen Med 2011; doi: $10.1002 /$ term.370.

[85] Hoynowski SM, Fry MM, Gardner BM, et al. Characterization and differentiation of equine umbilical cord-derived matrix cells. Biochem Biophys Res Commun 2007; 362: 347-53.

(C) Lo Iacono et al.; Licensee Bentham Open.

This is an open access article licensed under the terms of the Creative Commons Attribution Non-Commercial License (http://creativecommons.org/ licenses/by-nc/3.0/), which permits unrestricted, non-commercial use, distribution and reproduction in any medium, provided the work is properly cited. 